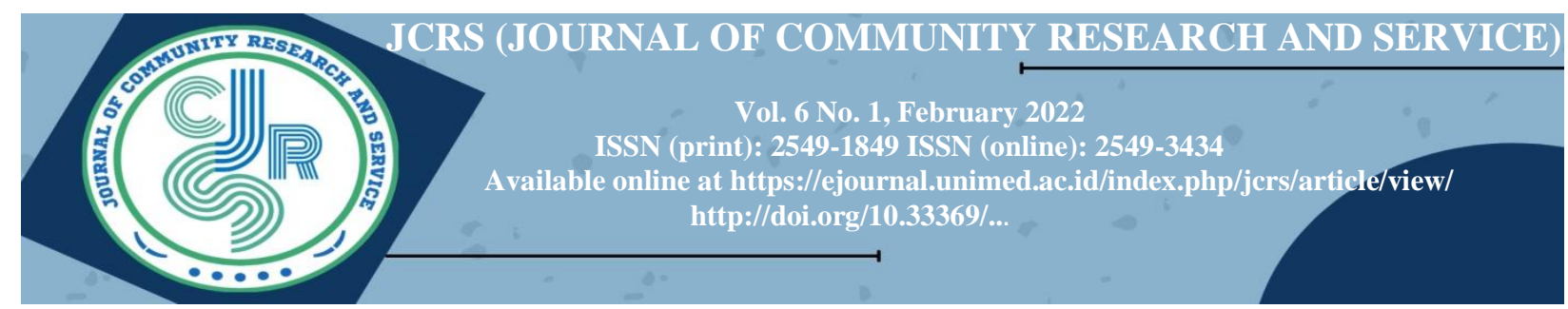

\title{
Pemanfaatan Limbah Minyak Jelantah Menjadi Sabun Berbasis Ecogreen dalam Meningkatkan Pendapatan Rumah Tangga di Desa Klambir Lima Kebun
}

\author{
${ }^{1}$ Erwansyah, ${ }^{2}$ Maya Macia Sari, ${ }^{3}$ Dewi Mahrani Rangkuty \\ ${ }^{1,2}$ Manajemen, Universitas Pembangunan Panca Budi, Medan, Indonesia \\ ${ }^{3}$ Ekonomi Pembangunan, Universitas Pembangunan Panca Budi \\ Medan, Indonesia \\ 1erwansyah@dosen.pancabudi.ac.id
}

\begin{abstract}
Abstrak Kegiatan kepada Masyarakat dengan judul "Pemanfaatan Limbah Minyak Jelantah Menjadi Sabun Berbasis Ecogreen Dalam Meningkatkan Pendapatan Rumah Tangga di Desa Klambir Lima Kebun, Kecamatan Hamparan Perak Kabupaten Deli Serdang" berguna untuk memberikan pengetahuan melatih membuat sabun Ecogreen dari minyak jelantah tersebut kepada masyarakat di Desa Klambir Lima Kebun Kecamatan Hamparan Perak Kabupaten Deli Serdang khususnya Ibu rumah tangga agar menambah pendapatan. Dari kegiatan ini diharapkan nantinya hasil limbah yang telah menjadi produk sabun Ecogreen dapat menyeimbangkan pemasukan dan pengeluaran rumah tangga pada masayarakat di Desa Klambir Lima Kebun, Kecamatan Hamparan Perak Kabupaten Deli Serdang.
\end{abstract}

Kata Kunci : Limbah Minyak Jelantah, Ecogreen, Pendapatan Rumah Tangga

Riwayat Artikel: Diterima: 23-11-2021, Direvisi: 12-12-2021, Disetujui: 24-02-2022, Tersedia online: 26-02-2022 Cara sitasi artikel: Erwansyah, Sari, M.M., Rangkuty D.M. (2022) Pemanfaatan Limbah Minyak Jelantah Menjadi Sabun Berbasis Ecogreen dan Meningkatakan Pendapatan Rumah Tangga di Desa Klambir Lima Kebun. Journal of Community Research and Service, 6(2), $\mathrm{xxx}-\mathrm{xxx}$.

https://doi.org/10.14710/ijred.X.X.Xxx-Xxx

\section{Pendahuluan}

Penurunan kualitas lingkungan dapat menyebabkan lingkungan tidak berfungsi sesuai dengan peruntukannya. Yang dimaksud dengan "kerusakan lingkungan" mengacu pada dua kategori bencana yang mempengaruhi kemampuan lingkungan untuk mendukung kehidupan. Kerusakan yang disebabkan oleh alam maupun kerusakan yang disebabkan oleh perbuatan manusia, dalam hal ini masyarakat, keduanya termasuk. Karena bencana alam bisa datang sewaktu-waktu, masyarakat tidak mungkin bersiap-siap menghadapi kerusakan yang akan ditimbulkannya. Ini dapat memiliki efek langsung, atau dapat memiliki efek jangka panjang. Kerusakan lingkungan yang disebabkan terutama oleh aktivitas manusia dengan tujuan meningkatkan kesejahteraan diri sendiri. Industrialisasi, penggunaan bahan bakar fosil, dan sampah rumah tangga yang dibuang ke sungai telah mengurangi kapasitas saluran air untuk mengangkut orang dan barang.

Minyak goreng bekas atau minyak goreng bekas merupakan salah satu limbah rumah tangga yang dapat berdampak negatif terhadap lingkungan. Minyak jelantah berpotensi mencemari tanah dan air jika tidak dibuang dan ditangani dengan baik. Limbah minyak jelantah merupakan sumber karsinogen dengan kandungan asam dan peroksida tinggi yang dapat menyebabkan kanker. Minyak jelantah yang tidak dikelola dengan baik dapat merembes ke dalam tanah dan mengganggu nutrisi tanah, dan jika minyak jelantah dibuang sembarangan maka tumpah ke sungai. Karena kurangnya nutrisi di tanah, pohon tidak bisa lagi tumbuh di sana. Selain itu, sistem TPA (Tempat Pemrosesan Akhir) di Indonesia terbuka, dan 
pasien sering dikirim ke sana tanpa perawatan. Akibatnya, ada peningkatan risiko pencemaran lingkungan, terutama di air dan tanah.

Untuk ini bagaimana mengelola limbah minyak jelantah tersebut yang sangat tepat dalam rangka usaha peningkatan pendapatan rumah tangga pada situasi Pandemi yang sedang dialami dunia sekarang ini, perlu adanya kreatifitas penunjang yang outputnya dapat mengasilkan keuntungan. Adanya ide yang sedang ingin dilakukan untuk meningkatkan hal tersebut yaitu pemanfaatan limbah minyak jelantah. Setiap rumah tangga pastinya menggunakan minyak goreng untuk kebutuhan pengolahan makanan dan pastinya juga terdapat sisa dari penggunaan minyak tersebut. Maka muncullah ide bagaimana memanfaatkan limbah minyak sisa yang biasanya disebut minyak jelantah untuk dijadikan sabun yang berbasis Ecogreen. Sasaran dalam pelaksanaan kegiatan ini adalah masyarakat yang khususnya Ibu rumah tangga selaku memegang peranan di dapur rumah tangga yang diharapkan dapat memberikan pengetahuan, melatih dan pada akhirnya mengasilkan pendapatan. Situasi yang menimpa dunia saat ini suka tidak suka kita selaku masyarakat harus tetap menyeimbangkan pemasukan dan pengeluaran kebutuhan hidup. Segala ide-ide perlu kita tumbuhkan dan segala peluang perlu juga kita tangkap. Dengan demikian apabila limbah ini tidak diolah dengan benar dapat mengakibatkan hal yg tidak dinginkan kedepannya, maka dari itu akan dikemas nantinya menjadi sabun yang berbasis Ecogreen.

Pada Desa Klambir Lima Kebun Kecamatan Hamparan Perak Kabupaten Deli Serdang terdapat beberapa permasahan yaitu kurangnya dalam hal pendapatan, apalagi pada masa pandemi ini, maka dari itu perlunya menyeimbangkan antara pemasukan dan pengeluaran dan kurangnya pengembangan kreatifitas pada masyarakat tersebut. Sedangkan solusi permasalahan yang menjadi prioritas yaitu membantu masyarakat terutama kaum Ibu rumah tangga untuk memanfaatkan limbah minyak jelantah menjadi sabun berbasis Ecogreen, meningkatkan pemahaman Ibu rumah tangga tersebut dalam pengembangan kreatifitasnya dan eningkatkan pemahaman Ibu rumah tangga tersebut dalam menentukan harga jual dan menjual produknya.

\section{Metode}

Demonstrasi adalah pendekatan yang sangat berhasil untuk menyampaikan informasi kepada publik karena mendorong audiens untuk memberikan tanggapan mereka sendiri berdasarkan fakta atau data yang akurat. Saat mengajar, pendekatan demonstrasi melibatkan memamerkan dan mendemonstrasikan kepada audiens bagaimana sesuatu bekerja, apakah itu proses, situasi, atau objek nyata. Tidak mungkin bagi seorang peneliti untuk memisahkan demonstrasi dari penjelasan lisan sebagai strategi presentasi. Metodologi pembelajaran ekspositori dan inkuiri dapat mengambil manfaat dari demonstrasi dalam bentuk alat bantu visual.

Menyikapi hal tersebut, maka diusulkan untuk dikembangkan ide pelatihan berikut di Desa Klambir Lima Kebun Kecamatan Hamparan Perak Kabupaten Deli Serdang: Pelatihan Pemanfaatan Limbah Minyak Goreng Menjadi Sabun Berbasis Ecogreen Dalam Meningkatkan Pendapatan Rumah Tangga:

1. Mendaftar kepada kepala lingkungan untuk mengikuti pelatihan dengan mematuhi protokol kesehatan yang telah ditetapkan.

2. Mempersiapkan tempat untuk pelatihan.

3. Mengikuti Pelatihan.

Diharapkan pelaksanaan kegiatan kepada masyarakat yang berjudul Pemanfaatan Limbah Minyak Jelantah menjadi Sabun Berbasis Ecogreen dalam Meningkatkan Pendapatan Rumah Tangga di Desa Klambir Lima Kebun, Kecamatan Hamparan Perak Kabupaten Deli Serdang ini hendaknya selalu dilakukan evaluasi, untuk memantau perkembangan kegiatan yang dilakukan untuk mengatasi permasalahan tersebut.

\section{Hasil dan Pembahasan}

Hasil kegiatan Masyarakat dengan tema Pemanfaatan Limbah Minyak Jelantah menjadi Sabun Berbasis Ecogreen dalam Meningkatkan Pendapatan Rumah Tangga di Desa Klambir Lima Kebun, Kecamatan Hamparan Perak Kabupaten Deli Serdang, sebagai berikut:

1. Masyarakat memahami sekali situasi pandemi yang banyak memberikan dampak perubahan salah satunya adalah sumber pendapatan. 
2. Masyarakat terutama kaum Ibu rumah tangga berpotensi sekali dalam pengembangan kreatifitas yang diberikan.

3. Kepala desa perlu untuk menggandeng Pemerintah Daerah dan jika perlu menggandeng pihak swasta membantu mengembangkan potensi masyarakat di desa tersebut.

4. Mempersiapkan segala hal yang diperlukan dalam mewujudkan pemanfataan limbah minyak jelantah tersebut yang nantinya dapat menjadi sumber pendapatan masyarakat tersebut.

5. Membuat kelompok usaha dan aturan-aturan yang diperlukan dalam menjalankan usaha tersebut.

6. Menggunakan segala media seperti internet, dan lain-lain untuk memperkenalkan dan mempromosikan hasil dari usaha yang dibuat oleh kelompok usaha masyarakat tersebut agar lebih efektif dan efisien.

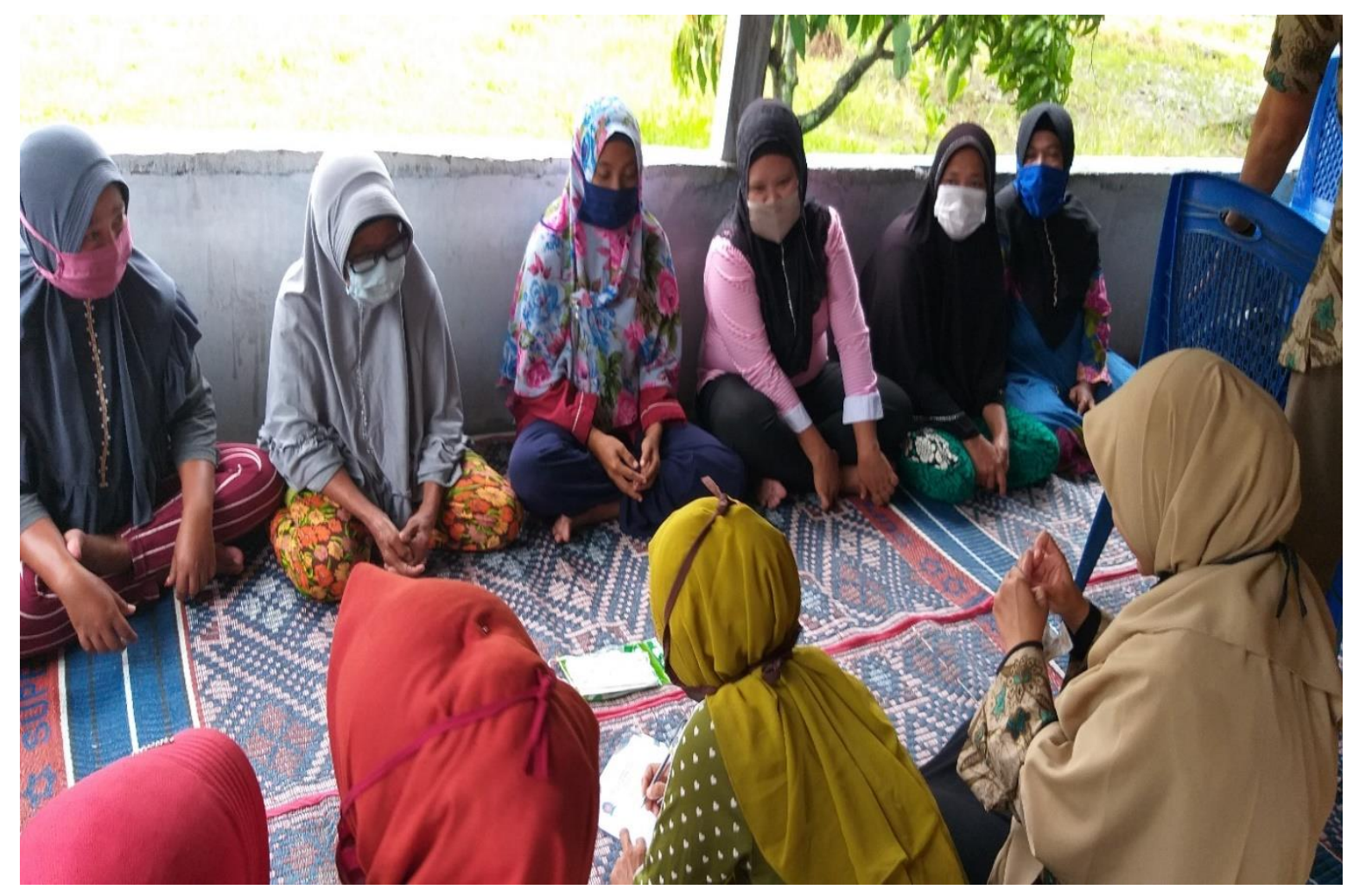

Gambar 1. Masyarakat sedang Mendengarkan Pengarahan Kegiatan.

Untuk membuat sabun berbasis Ecogreen dari minyak jelantah, anggota kelompok usaha ibu rumah tangga Desa Klambir Lima Kebun, Kecamatan Hamparan Perak, dan ibu rumah tangga Kabupaten Deli Serdang berkumpul di halaman rumah kepala desa. Masalah kesehatan penggunaan minyak jelantah berkali-kali atau yang dikenal dengan istilah "minyak jelantah" belum sepenuhnya dipahami oleh para ibu rumah tangga yang memiliki pemahaman yang terbatas tentang nilai ekonomisnya dan cara mengolahnya menjadi barang yang berpotensi mendongkrak keluarga. penghasilan. Sabun cuci piring berbahan minyak goreng bekas dapat dikemas dan dijual sebagai peluang wirausaha bagi peserta dan dapat digunakan di rumah sendiri sebagai kebutuhan rumah tangga. Karena para ibu memiliki reaksi positif dan sangat ingin berpartisipasi, instruksi ini diterima dengan baik.

Masyarakat yang mengikuti pelatihan diberikan penjelasan mengenai tahapan pembuatan sabun dari minyak goreng bekas, dengan teknik sebagai contoh cara pembuatannya berikut ini:

1. Alat \& Bahan yang digunakan:

a) Minyak Jelantah limbah rumah masing agar kita tau sumber jelantah bekas apa, dan memastikan kebersihannya.

b) $\mathrm{NaOH}$, ini basa/alkali yang akan digunakan dalam pembuatan sabun, bisa dibeli di toko bahan kimia atau toko bahan bangunan dengan nama soda api, berbentuk kristal flakes berwarna putih, hati-hati gatel kalo langsung kena kulit, pakai sendok plastik atau stainless untuk mengambilnya.

c) Arang kayu, arang batok yang ada di rumah.

d) Kain kaos bekas yang bersih atau saringan.

e) Kopi, pandan atau sereh (pilih salah satu)

f) Air, wadah, baskom, gelas ukur, sendok dari bahan plastik tahan panas atau stainless. 
g) Pengaduk kayu, plastik atau stainlessi, cetakan silikon atau loyang plastic atau dus bekas yang dialasi plastik tahan panas.

h) Timbangan digital, sarung tangan, masker \& kacamata pelindung.

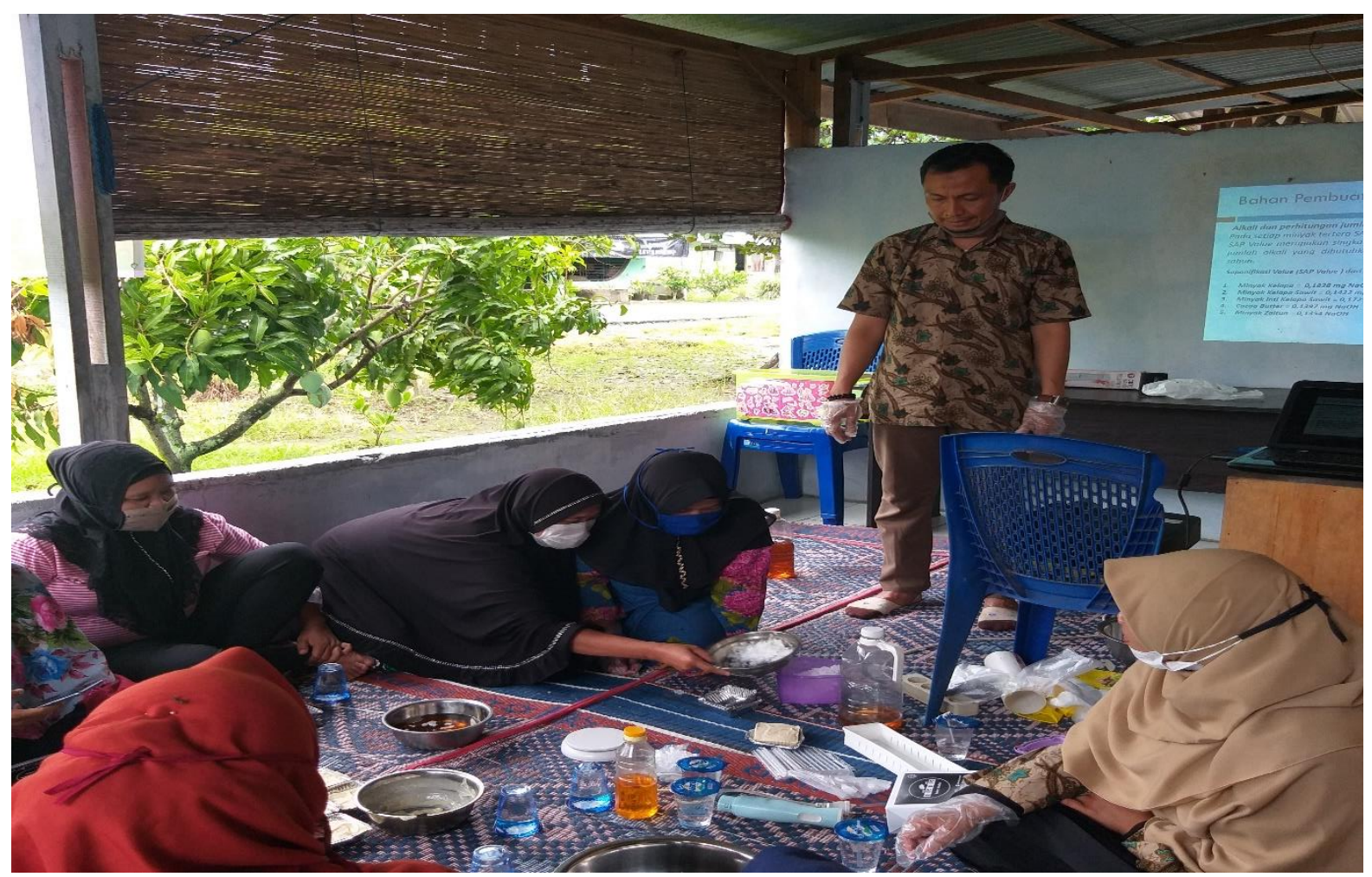

Gambar 2. Mempersiapkan Alat dan Bahan yang akan Digunakan untuk Kegiatan.

2. Cara Membersihkan Jelantah:

a) Masukkan arang ke dalam jelantah, diamkan selama 1-2 hari. Bisa arang dingin atau arang panas (arang yang dibuat jadi bara lebih dulu). Ukuran arang usahakan agak kecil jangan bongkahanbesar supaya permukaan yang kontak dengan minyak makin banyak.

b) Setelah 1-2 hari (boleh lebih lama) saring jelantah dengan kain bekas yang bersih.

c) Jelantah siap digunakan untuk membuat sabun.

3. Bahan yang digunakan:

a) $1 / 2 \mathrm{~L}$ atau sekitar 450 gram jelantah yang sudah bersih.

b) 80 gram $\mathrm{NaOH}$.

c) 170gram air, air kopi, air blenderan pandan atau sereh, saring lalu timbang hasilnya sampai 170gram, air biasa tanpa apa-apa sebenarnya bisa, tapi kopi, pandan atau sereh kita gunakan supaya sabun lebih enak aromanya, aroma jelantah sangat tersamarkan.

4. Tahap pembuatan:

a) Larutkan $\mathrm{NaOH}$ sedikit-sedikit ke dalam air (air kopi, air pandan atau airsereh).

b) Aduk perlahan, masukkan $\mathrm{NaOH}$ ke air, aduk lagi, sampai $\mathrm{NaOH}$ habis.

c) Reaksi $\mathrm{NaOH}$ dengan air merupakan reaksi eksoterm yang mengeluarkan panas.

d) Setelah larutsemua, diamkan sampai suhu turun menjadi suhu ruang (suhu air biasa).

e) Setelah dingin, masukkan jelantah sedikit-sedikit sambil diaduk dengan sendok/pengaduk kayu, aduk terus sekitar 15-20 menit sampai trace. Trace ditandai dengan kental berjejak ketika pengaduk diangkat.

f) Masukkan ke dalam cetakan silikon atau ke dalam loyang plastik.

g) Diamkan selama 12-24 jam sampai mengeras.

h) Keluarkan sabun dari cetakan.

i) Simpan dalam wadah terbuka, biarkan di ruangan terbuka yang terlindung selama 3-4 minggu. (Proses Curing).

j) Sabun siap digunakan untuk mencuci piring, lap, membersihkan kamar mandi, dll. (Tidak untuk mandi). 


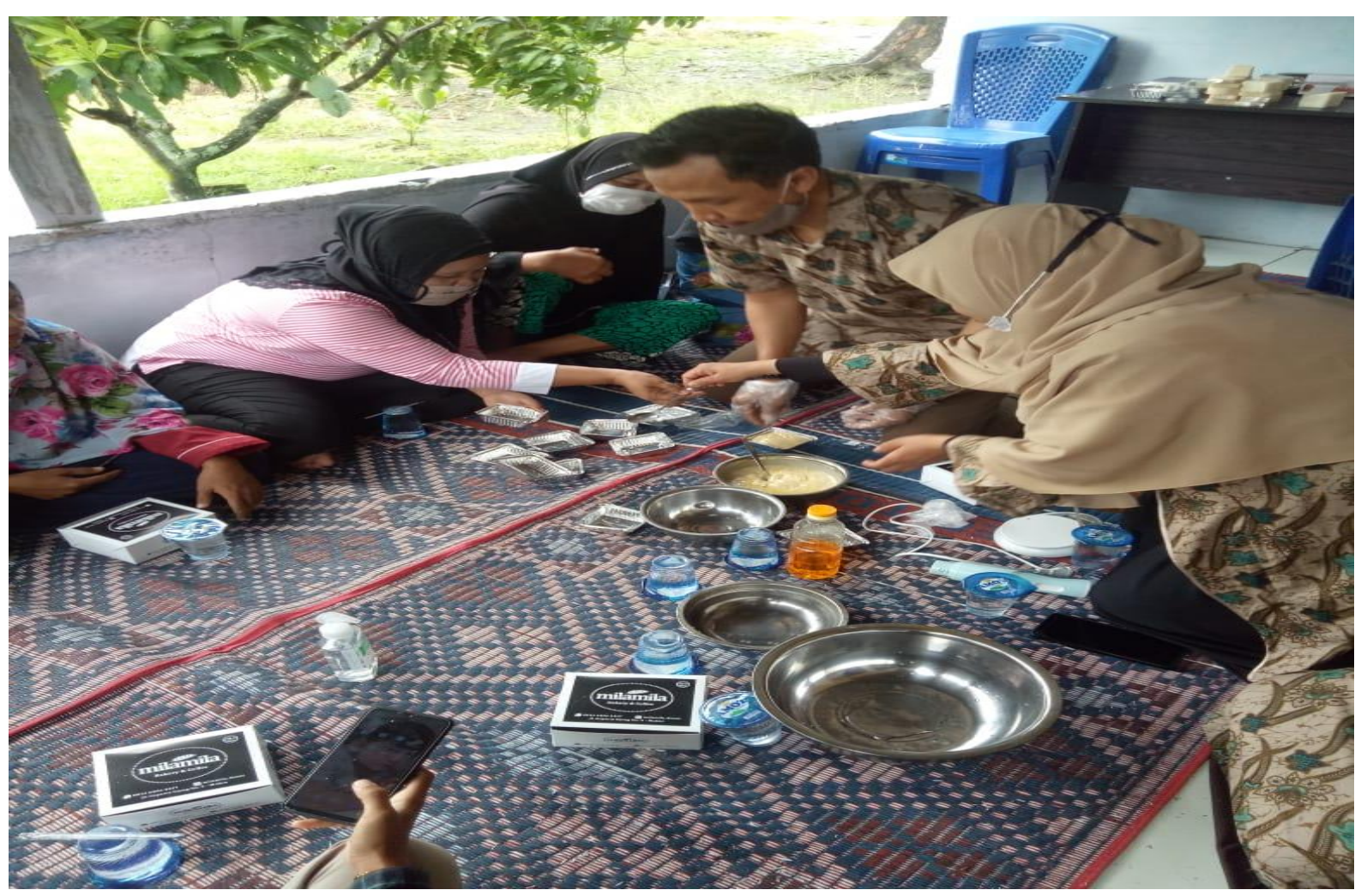

Gambar 3. Proses Pembuatan Minyak Jelantah menjadi Sabun.

Sebagai tindakan pencegahan, limbah minyak goreng bekas harus dibuang dengan cara yang ramah lingkungan. Limbah minyak goreng masih dibuang di tempat pembuangan sampah oleh banyak anggota masyarakat umum dan profesional layanan makanan karena kurangnya kesadaran tentang dampak lingkungan. Dusun Klambir Lima Kebun Kecamatan Hamparan Negara Bagian Perak Ibu-ibu rumah tangga membuang limbah minyak jelantah di Kabupaten Deli Serdang yang berpotensi untuk dijadikan sabun dan sektor usaha untuk meningkatkan perekonomian. Kami membutuhkan waktu sekitar 1 (satu) bulan untuk menyelesaikan proses produksi, mulai dari pembelian bahan, percobaan, dan mencapai hasil terbaik, hingga pengemasan. Kami menetapkan bahwa masyarakat antusias menggunakan minyak jelantah untuk pembuatan sabun berbasis ecogreen, yang menurut mereka sangat bermanfaat bagi perekonomian, baik dari sisi penghematan maupun peningkatan pendapatan rumah tangga.

Memurnikan minyak jelantah dan sabun padat untuk penggunaan jangka panjang adalah dua tantangan utama yang mereka hadapi. Solusi yang kami tawarkan adalah kembali memotivasi masyarakat untuk menggalakkan pemanfaatan sampah menjadi produk alternatif yang berguna untuk memberikan pengetahuan kepada masyarakat tentang potensi ekonomi dari limbah minyak jelantah dan pelatihan keterampilan membuat sabun cuci piring ramah lingkungan dari minyak goreng bekas.. Anggota masyarakat sangat antusias mengikuti kegiatan ini, terlihat dari banyaknya pertanyaan yang mereka ajukan dan keinginan mereka untuk mengikuti kegiatan ini. Produk sabun diproduksi di akhir kursus dan diberikan kepada ibu untuk digunakan sendiri. Besar harapan bahwa pengembangan bakat yang telah mereka pelajari di masa depan akan menghasilkan imbalan finansial. 


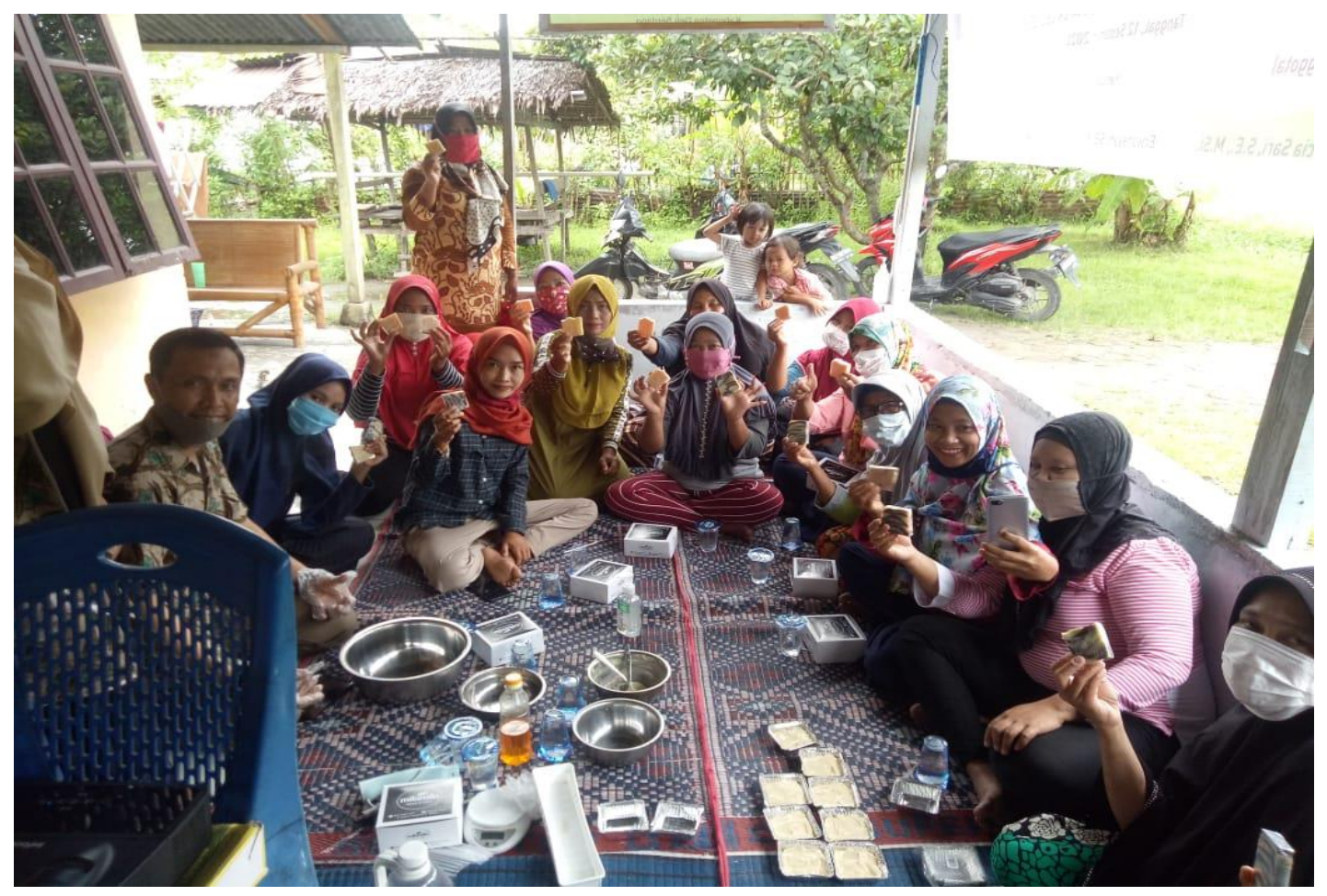

Gambar 4. Hasil Pembuatan Minyak Jelantah menjadi Sabun Ecogreen.

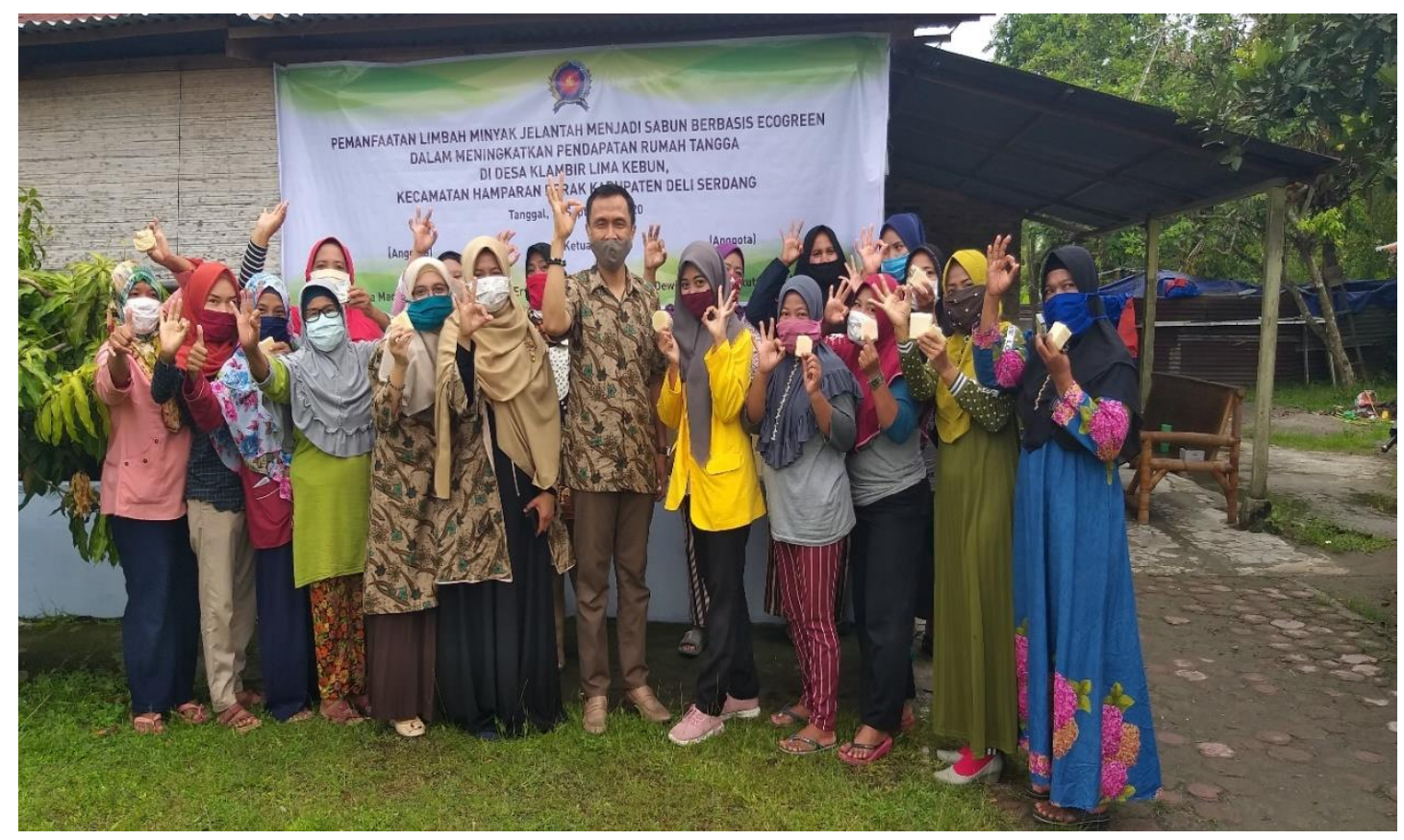

Gambar 5. Foto Bersama Kelompok Usaha Ibu Rumah Tangga dan Memegang Sabun hasil Kegiatan.

\section{Kesimpulan}

Penggunaan minyak goreng bekas secara berulang-ulang berdampak buruk bagi kesehatan tubuh. Jika dibuang ke lingkungan, akan mencemari lingkungan dan merugikan masyarakat sekitar. Untuk mengatasi permasalahan tersebut, diadakan kegiatan berbasis masyarakat yang bertujuan untuk mengedukasi masyarakat tentang potensi ekonomi dari pemanfaatan limbah minyak jelantah untuk membuat sabun berbasis Ecogreen. Anggota masyarakat sangat antusias untuk mengikuti kegiatan ini, terlihat dari banyaknya pertanyaan yang mereka ajukan dan keinginan mereka untuk mengikuti kegiatan 
ini. Produk sabun diproduksi di akhir kursus dan diberikan kepada ibu untuk digunakan sendiri. Besar harapan bahwa pengembangan bakat yang telah mereka pelajari di masa depan akan menghasilkan imbalan finansial.

\section{Referensi}

[1] Pedoman Lembaga Penelitian Pengabdian masyarakat Universitas Pembangunan Panca Budi Tahun 2019.

[2] Kusumaningtyas, Dewi Ratna dkk.(2018). Penerapan Teknologi Pengolahan Limbah Minyak Goreng Bekas MenjadiSabun Cuci Piring Untuk Pengendalian Pencemaran dan Pemberdayaan Masyarakat. Jurnal Abdimas Vol. 22 (2). Fakultas Teknik Universitas Negeri Semarang: Semarang

[3] Rini Safrianti, "Metode Demontrasi Dalam Pembelajaran", (Kompasiana, 14 September 2017), diakses https://www.kompasiana.com/rinisafrianti/59ba31f2a32cdd2ec014af92/metode-demonstrasidalam-pembelajaran?page=all, pada 13 September 2020 Pukul 15:00 WIB

[4] Wikipedia, “Klambir Lima Kebon, Hamparan Perak, Deli Serdang”, (Wikipedia Indonesia, 9 Maret 2020), diakses

melalui https://www.google.com/search?q=Klambir+Lima+Kebon,+Kabupaten+Deli+Serdang, + Sumatera+ Utara\&safe $=$ strict \&source $=$ lnms\&tbm $=$ isch\&sa $=$ X\&ved $=2$ ahUKEwiag 861 dvrAhXSXisKHcttCGIQ AUoA3oECBgQBQ\&biw=940\&bih=486, pada 13 September 2020 Pukul 15:00 WIB 